\title{
Genetic discontinuity of Digenea (Rhodomelaceae, Rhodophyta) from Mexico supports recognition of two new species, $D$. mexicana and $D$. rafaelii
}

\author{
Ga Hun Boo ${ }^{1}$, Daniel Robledo ${ }^{2}$, Gabriella Andrade-Sorcia ${ }^{3}$ and Sung Min Boo ${ }^{4, *}$ \\ ${ }^{1}$ University Herbarium, University of California Berkeley, 1001 Valley Life Sciences Building \#2465, Berkeley, CA 94720, USA \\ ${ }^{2}$ Department of Marine Resources, Centro de Investigación y Estudios Avanzados Unidad Mérida, Yucatán, CP 97310, Mexico \\ ${ }^{3}$ Programa de Investigación en Botánica Marina, Departamento de Biología Marina, Universidad Autónoma de Baja \\ California Sur, Carretera al sur 5.5 km, P.C. 23080, 19-B, La Paz, Baja California Sur, México \\ ${ }^{4}$ Department of Biology, Chungnam National University, Daejeon 34134, Korea
}

Genetic continuity of Digenea simplex outside the Atlantic waters remains less studied, despite its long exposure to oriental folk medicine and wide distribution in tropical waters. Mitochondrial COI-5P and plastid $r b c \mathrm{~L}$ sequences and morphology were investigated for plants from Mexico and additional specimens from Japan. Two new species, Digenea mexicana and Digenea rafaelii, are described for plants that would previously have been recognized as $D$. simplex in Mexico. D. mexicana grows to $10.5 \mathrm{~cm}$ tall and has cylindrical axes, irregular or di-, trichotomous branches, simple to branched determinate branchlets with eight pericentral cells, and tetrasporangia on inflated upper parts of determinate branchlets. It occurs intertidally in Quintana Roo, Yucatan Peninsula. D. rafaelii grows to $5 \mathrm{~cm}$ tall and has cylindrical axes, irregular or di-, trichotomous branches, and simple determinate branchlets with ten pericentral cells. It occurs intertidally in the Gulf of California. Both COI-5P and $r b c \mathrm{~L}$ sequences revealed the genetic discontinuity between $D$. mexicana and D. rafaelii.

Key Words: COI-5P; Gulf of California; medicinal seaweeds; morphology; phylogeny; rbcL; species complex; Yucatan Peninsula

\section{INTRODUCTION}

Digenea C. Agardh is a rhodomelacean red algal genus that until recently was regarded as monospecific, including only Digenea simplex (Wulfen) C. Agardh (Agardh 1822). D. simplex is widely known as one of the most efficient anthelmintic treatments in oriental folk medicine (Tseng 1983, Trono 1997, Ebadi 2006). The species is also of interest as a source of polysaccharides inhibiting inflammatory and nociceptive responses and the production of carrageenan (Takano et al. 2003, Pereira et al. 2014). Since its first recognition in the Adriatic Sea, D. simplex has been recorded from numerous locations and is now regarded as having a pantropical distribution in the northern and southern hemisphere (Pakker et al. 1996, Silva et al. 1996, Orfanidis and Breeman 1999, Guiry and Guiry 2018).

Agardh (1822) established Digenea to accommodate
(1) $\$$ This is an Open Access article distributed under the terms of the Creative Commons Attribution Non-Commercial License (http://creativecommons.org/licenses/by-nc/3.0/) which permits unrestricted non-commercial use, distribution, and reproduction in any medium, provided the original work is properly cited.
Received July 8, 2018, Accepted August 20, 2018

* Corresponding Author

E-mail: smboo@cnu.ac.kr

Tel: +82-42-936-4376, Fax: +82-42-822-9690 
a species previously known as Conferva simplex Wulfen. The genus is characterized by terete, polysiphonous axes, with branches that are densely surrounded by short, stiff, simple filamentous branchlets (Agardh 1822, Kylin 1956, Norris 2014). A second species, Digenea subarticulata Simons, was described for plants from KwaZulu-Natal, South Africa (Simons 1970), however, De Clerck et al. (2005) noted that the species likely belongs to the genus Bryocladia F. Schmitz. Recently, Digenea arenahauriens C. W. Schneider, Hamzeh \& G. W. Saunders from Bermuda and D. cymatophila (R. E. Norris) Díaz-Tapia \& Maggs from Hawaii have been added in the genus (Díaz-Tapia et al. 2017, Schneider et al. 2018).

The apparent pantropical distribution of D. simplex has been the focus of biogeographical and taxonomic studies. For example, Pakker et al. (1996) found that Pacific isolates of $D$. simplex survive a broader range of temperatures than Atlantic populations, which may be correlated to local temperature extremes. Orfanidis and Breeman (1999) reported that ecological variation in $D$. simplex was related to the lower tolerance limits of temperature, indicating that the pantropical distribution may be related to evolutionary pressures. Based on DNA sequences and morphology, Schneider et al. (2018) described $D$. arenahauriens for plants from Bermuda that were previously known as $D$. simplex. However, there have been no studies on plants outside the Atlantic, where D. simplex is reported to commonly occur (e.g., Yoshida 1998, Norris 2014).

Plants referable to D. simplex occur abundantly in the intertidal to subtidal zones of the Yucatan Peninsula and the Gulf of California, Mexico (Dawson 1963, Dreckmann and Sentíes 1994, Norris 2014). Quintana Roo on the east of the Yucatan Peninsula is an adjacent rocky coast to the Caribbean Sea, comprising mostly sandy bottom, subtidal rocky platforms exposed to the swell, and rockysand substrata in reef lagoons. Compared to many studies on the Gulf of California (e.g., Norris 2010, 2014), little is known about marine algae from Quintana Roo because many coastal areas remain unexplored or no descriptions have been made using recent molecular tools. We focused on the genetic discontinuity between $D$. simplex specimens from the Yucatan Peninsula and the Gulf of California. We studied morphology and analyzed mitochondrial COI-5P and plastid $r b c \mathrm{~L}$ sequences, as commonly used in taxonomic studies of red algae (e.g., Boo et al. 2016a, 2016b, Schneider et al. 2018). On the basis of morphology and two genes sequences, we propose two new species of Digenea, one from Yucatan Peninsula and the other from the Gulf of California.

\section{MATERIALS AND METHODS}

Samples of Digenea were collected from low intertidal zones of the Yucatan Peninsula and the Gulf of California, Mexico, and additional samples from Japan were included (Supplementary Table S1). Vouchers were mounted on herbarium sheets and subsamples were dehydrated in silica gel for molecular analysis. Herbarium specimens in the Herbario Nacional de México (MEXU) of Universidad Nacional Autónoma de México were examined on loan. Vegetative and reproductive structures were observed under a microscope. For anatomical observations, plants were sectioned using razor blades and were stained with $1 \%$ aqueous aniline blue. Photographs were taken with a DP-71 camera (Olympus, Tokyo, Japan) mounted on a BX-51 microscope (Olympus). Types and voucher specimens are housed at the Herbarium of the Department of Biology, Chungnam National University, Daejeon, Korea (CNUK) and MEXU of the Universidad Nacional Autónoma de México. Abbreviations of herbaria follow the online Index Herbariorum (Thiers 2018).

DNA extraction, polymerase chain reaction amplification, and sequencing were performed as described in Boo et al. (2013). The primers used for amplifying and sequencing were $r b c \mathrm{LJNF1-rbcLJNR1} \mathrm{and} \mathrm{R753-RrbcS}$ start for $r b c \mathrm{~L}$ (Freshwater and Rueness 1994, Kang and Kim 2013), and GWSFn-GazRx for COI-5P (Saunders and Moore 2013). Sequences of COI-5P and $r b c \mathrm{~L}$ generated in this study were deposited in GenBank (Benson et al. 2018). A total of 17 COI-5P sequences (664 bp) were aligned, including sequences of other species of Digenea previously published in GenBank. Seventeen $r b c \mathrm{~L}$ sequences $(1,220 \mathrm{bp})$ were aligned including sequences of other species of Digenea previously published in GenBank and three outgroup taxa, Alsidium corallinum C. Agardh, Bryothamnion seafortii (Turner) Kützing, and $B$. triquetrum (S. G. Gmelin) M. Howe (Supplementary Table S1). However, we used phylogeny of COI-5P without outgroups because branch lengths of ingroups were too short to recognize each species.

Phylogenies of COI-5P and $r b c \mathrm{~L}$ datasets were inferred using maximum likelihood (ML) and Bayesian inference (BI). The ML analyses were performed using the Pthreads version of RAxML v8.0.X (Stamatakis 2014) set as follows: a rapid bootstrap analysis and search for the best-scoring ML tree in one single program run with 1,000 bootstrap replicates under GTRGAMMA model. BI was performed for individual datasets with MrBayes v.3.2.1 (Ronquist et al. 2012) using the Metropolis-coupled Markov Chain Monte Carlo (MC3) with the GTR + G + I model. For each 
matrix, four million generations of two independent runs were performed with four chains and sampling trees every 100 generations. The burn-in period was identified graphically by tracking the likelihoods at each generation to determine whether they reached a plateau. Twenty-five percent of saved trees were removed, and the remaining trees were used to infer Bayesian posterior probabilities (BPP).

\section{RESULTS}

\section{Digenea mexicana G. H. Boo \& D. Robledo sp. nov. (Fig. 1A-J)}

Description. Plants bushy, up to $10.5 \mathrm{~cm}$ high, tough and cartilaginous (Fig. 1A-C); axes sometimes denuded in lower portions, attached by a discoid holdfast which often spreads and may possibly coalesce with other holdfasts; axes terete, irregularly, widely dichotomously or rarely trichotomously branched (Fig. 1B \& C); axes and indeterminate branches usually densely (or occasionally sparsely) clothed with wiry, stiff, simple or branched, determinate branchlets of $6.5 \mathrm{~mm}$ in length and 90-135 $\mu \mathrm{m}$ in width (Fig. 1F); branchlets polysiphonous, with axial cells 20-30 $\mu \mathrm{m}$ in diameter (Fig. 1D), 8 or rarely 9 pericentral cells surrounded by about 20 cortical cells in one layer (Fig. 1G \& H); surface cortical cells oblong, irregularly or longitudinally arranged, in packets of 2-4 cells (Fig. 1E); apices with short vegetative trichoblasts remaining during development; tetrasporangia formed on swollen determinate branchlets, tetrahedrally divided, ellipsoidal to globose, $40-70 \mu \mathrm{m}$ in diameter (Fig. 1I \& J); sexual reproductive structures not found.

Holotype. CNU080663 deposited in CNUK, Herbarium of Chungnam National University, Daejeon, Korea; a tetrasporophyte specimen; collected at Playa Xcalacoco $\left(20^{\circ} 39^{\prime} 42.84^{\prime \prime} \mathrm{N}, 87^{\circ} 01^{\prime} 56.78^{\prime \prime} \mathrm{W}\right)$, Quintana Roo, Mexico on Apr 19, 2018 by Daniel Robledo.

Isotypes. CNU080664, CNU080665, CNU080666, and CNU080668 in CNUK, Korea.

Additional herbarium specimens observed. MEXU 2310 (as D. simplex determined by José Luis Godínez Ortega; Morro de la Mancha, Veracruz; Nov 8, 2013), MEXU 2326 (as D. simplex determined by José Luis Godínez Ortega; Morro de la Mancha; May 18, 2013), MEXU 2357 (as $D$. simplex determined by José Luis Godínez Ortega; Morro de la Mancha; Oct 20, 2011), MEXU 2371 (as D. simplex determined by José Luis Godínez Ortega; Mandinga, Veracruz; Apr 7, year unknown), CNU080681
(Playa Xcalacoco, Quintana Roo, Mexico; Jun 16, 2018), CNU080682 (Playa Xcalacoco; Jun 16, 2018), CNU080683 (Playa Xcalacoco; Jun 16, 2018), CNU080684 (Playa Xcalacoco; Jun 16, 2018).

Etymology. The specific epithet refers to Mexico, where the plants were collected.

Distribution and habitat. Presently confirmed in Playa Xcalacoco, Quintana Roo, Yucatan Peninsula and likely extended to the Gulf of Mexico. D. mexicana populations were found growing on intertidal rock, calcareous corallines and reef formations, which are often covered by sands. They formed patches or mats of $1-2 \mathrm{~m}^{2}$ in area (Fig. 1A).

DNA sequences of type specimens. For holotype, MH514874 (COI-5P) and MH514862 ( $r b c \mathrm{~L})$; for isotypes, MH514875-MH514878 (COI-5P) and MH514863MH514866 (rbcL).

\section{Digenea rafaelii G. H. Boo, G. Andrade-Sorcia \& S. M. Boo sp. nov. (Fig. 2A-F)}

Description. Plants bushy, up to $5 \mathrm{~cm}$ high, tough and cartilaginous; axes widely di-, trichotomous or irregularly laterally branched (Fig. 2A \& B); axes denuded at base or sparsely covered with wiry branchlets, $1.9 \mathrm{~mm}$ wide; branches usually densely (or occasionally sparsely) clothed with slender, stiff, usually simple determinate branchlets, 2-3 $\mathrm{mm}$ long and 98-270 $\mu \mathrm{m}$ wide (Fig. 2D); primary axes sometimes denuded in lower portions; attached by a discoid holdfast which often spreads and may possibly coalesce with other holdfasts; branchlets polysiphonous, with axial cells $30-60 \mu \mathrm{m}$ in diameter, 10 or rarely 8 pericentral cells surrounded by up to 30 cortical cells in one layer (Fig. 2E); surface cortical cells irregular, in packets of 2-4 cells (Fig. 2C); apices with short vegetative trichoblasts remaining during development (Fig. 2F); reproductive structures not found.

Holotype. CNU037775 deposited in CNUK; a vegetative specimen; collected at Bahia de Kino $\left(28^{\circ} 88^{\prime} 71^{\prime \prime} \mathrm{N}\right.$, $112^{\circ} 04^{\prime} 96^{\prime \prime}$ W), Las Cruces, Sonora, Mexico on May 16, 2010 by Sung Min Boo.

Isotypes. CNU037775-1, CNU037775-2, and CNU0377 75-3 in CNUK, Korea.

Additional herbarium specimens observed. $\mathrm{CNU}$ 058249 (Conquista Agraria, Baja California Sur, Mexico; Feb 27, 2014), CNU058249-2 (Conquista Agraria; Feb 27, 2014), CNU058291 (Cabo San Lucas, Baja California Sur, Mexico; Mar 1, 2014).

Etymology. The specific epithet honors the departed saint Rafael Riosmena-Rodriguez, previous Professor of 


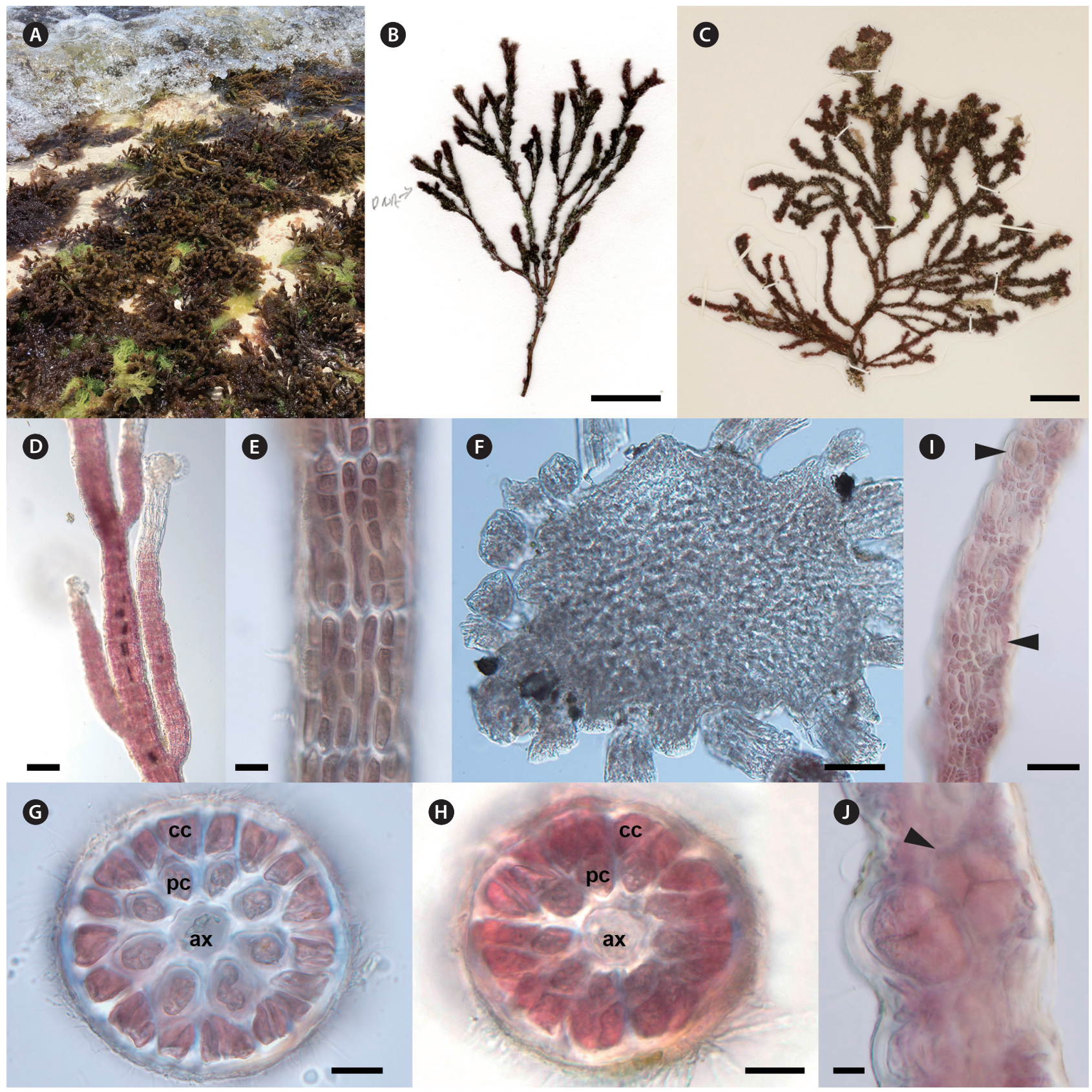

Fig. 1. Digenea mexicana sp. nov. G. H. Boo \& D. Robledo. (A) Plants growing intertidally on sand covered rocks at Playa Xcalacoco, Quintana Roo, Mexico (type locality). (B) Type specimen (CNU080663). (C) Paratype specimen from Veracruz (MEXU 2326). (D) Alternate determinate branches (CNU080683). (E) Surface view of determinate branch showing cortical cell packets covering pericentral cells (CNU080681). (F) Transverse section of indeterminate branch showing radiating determinate branchlets (CNU080682). (G) Transverse section of determinate branchlet having eight pericentral cells (pc) around axial cell (ax) and a single layer of outer cortical cells (cc) (CNU080682). (H) Transverse section of determinate branchlet having nine pericentral cells (pc) around axial cell (ax) and a single layer of outer cortical cells (cc) (CNU080681). (I) Swollen determinate branchlet with tetrasporangia (arrowheads) (CNU080684). (J) Tetrahedrally divided tetrasporangia (arrowhead) (CNU080684). Scale bars represent: B \& C, 2 cm; D, F \& I, $100 \mu \mathrm{m} ; \mathrm{E}, \mathrm{G}, \mathrm{H} \& \mathrm{~J}, 20 \mu \mathrm{m}$. 

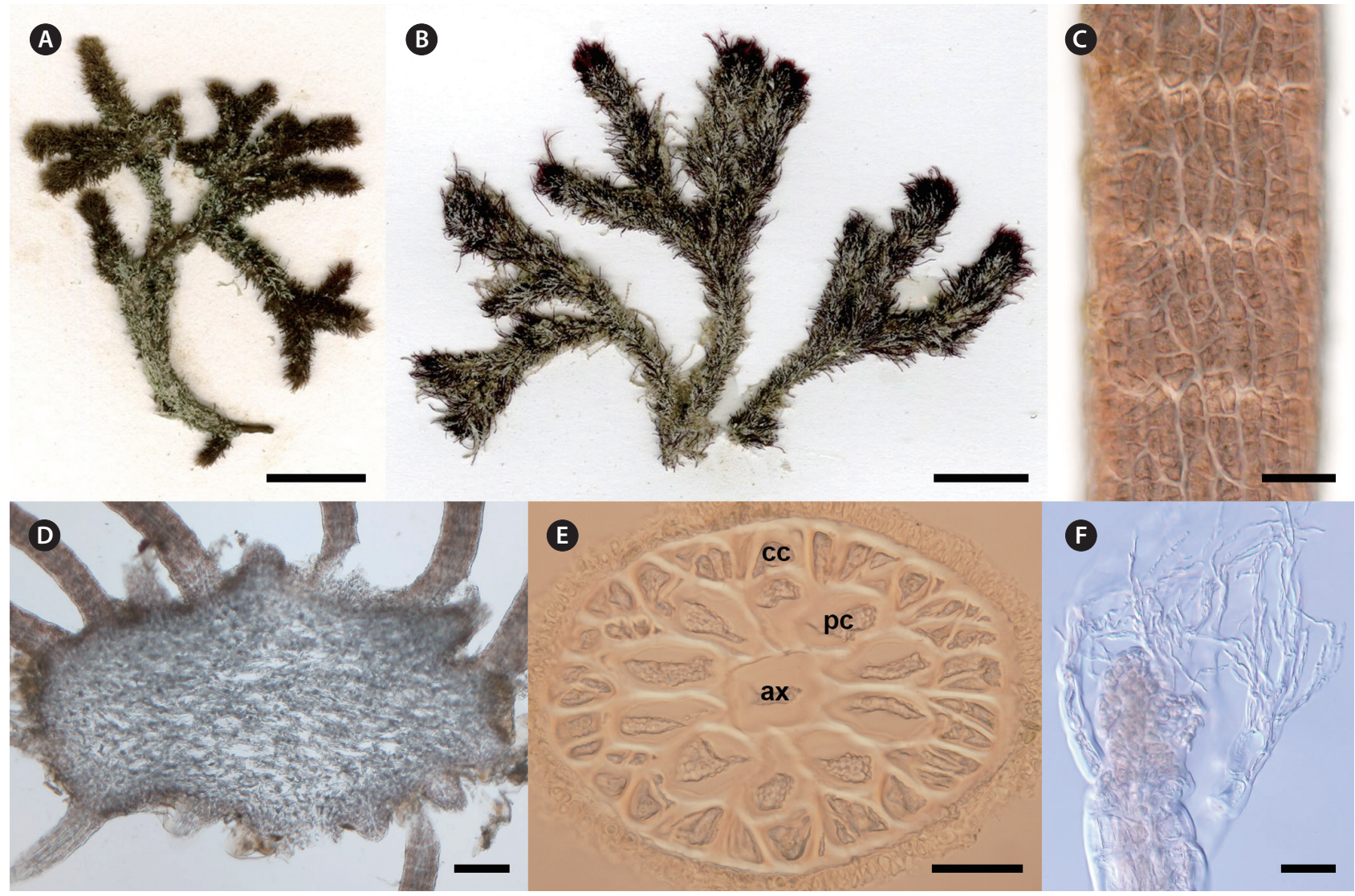

Fig. 2. Digenea rafaelii sp. nov. G. H. Boo, G. Andrade-Sorcia \& S. M. Boo. (A) Type specimen (CNU037775). (B) Paratype specimen from Conquista Agraria (CNU58249). (C) Surface view of determinate branchlet showing cortical cell packets covering pericentral cells (CNU037775). (D) Transverse section of indeterminate branch showing radiating determinate branchlets (CNU037776). (E) Transverse section of determinate branchlet having ten pericentral cells (pc) around axial cell (ax) and a single layer of outer cortical cells (cc) (CNU037775). (F) Apices with short vegetative trichoblasts (CNU037775). Scale bars represent: $A \& B, 1$ cm; C, E \& F, $50 \mu \mathrm{m} ; \mathrm{D}, 200 \mu \mathrm{m}$.

Departamento de Biología Marina, Universidad Autónoma de Baja California Sur, La Paz, Mexico, for his outstanding contributions to the marine algae in Mexico.

Distribution and habitat. Presently confirmed in Bahia de Kino, Sonora and Cabo San Lucas, Conquista Agraria, and Las Conchas, Baja California Sur. Plants were collected on sand covered rocks in mid to low intertidal or sometimes in sublittoral zones.

DNA sequences of type specimens. For holotype, MH514879 (COI-5P) and MH514867 (rbcL); for isotype, MH514880 (COI-5P) and MH514868 (rbcL).

A morphological comparison of $D$. mexicana and $D$. rafaelii with all other species of Digenea is provided in Table 1.

\section{Mitochondrial COI-5P and plastid rbcL phylog- enies}

Twenty-four sequences were generated in this study: five of COI-5P and $r b c \mathrm{~L}$ from each new species (here assigned to D. mexicana sp. nov. and D. rafaelii sp. nov.), respectively, and two each of COI-5P and $r b c \mathrm{~L}$ for $D i$ genea plants from Japan (Supplementary Table S1). All five plants of $D$. mexicana were identical in COI-5P and $r b c \mathrm{~L}$, and plants of $D$. rafaelii from four locations in the Gulf of California were also the same in both markers. D. mexicana differed by $3.6 \%$ in COI-5P and $2.5-2.7 \%$ in $r b c \mathrm{~L}$ from $D$. rafaelii and by 3.0-3.4\% in COI-5P and 0.98$1.07 \%$ in $r b c \mathrm{~L}$ from $D$. arenahauriens. Digenea plants from Japan and Western Australia differed by $3.9-4.2 \%$ in 
COI-5P from $D$. simplex from Tunisia.

The topology of the ML and BI trees was largely congruent, and only the ML tree is shown for COI-5P and $r b c \mathrm{~L}$ (Figs $3 \& 4$ ). In the COI-5P phylogeny (Fig. 3), D. mexicana and D. rafaelii were distinct enough to be segregated from other species of Digenea. However, Digenea plants from Japan and Australia did not form a clade with

\section{D. simplex from the Mediterranean.}

In the $r b c$ L phylogeny (Fig. 4), the monophyly of the genus Digenea was strongly supported (100\% ML, 1.0 BPP). D. rafaelii from the Gulf of California was placed outside the group of $D$. arenahauriens, $D$. mexicana, and D. simplex. Phylogenetic relationships of D. mexicana with other species were not resolved.

Table 1. A comparison of Digenea mexicana and D. rafaelii with other species of Digenea

\begin{tabular}{|c|c|c|c|c|c|c|}
\hline Feature & D. mexicana & D. rafaelii & D. arenahauriens & D. cymatophila & D. simplex & D. subarticulata \\
\hline Type locality & $\begin{array}{l}\text { Playa Xcalacoco, } \\
\text { Quintana Roo, } \\
\text { Mexico }\end{array}$ & $\begin{array}{l}\text { Bahia de Kino, La } \\
\text { Cruses, Sonora, } \\
\text { Mexico }\end{array}$ & $\begin{array}{l}\text { Captain William's } \\
\text { Bay, south shore } \\
\text { of Bermuda Is., } \\
\text { Bermuda }\end{array}$ & $\begin{array}{l}\text { West end of Koko } \\
\text { Head Parking, } \\
\text { O'ahu Island, } \\
\text { Hawaii }\end{array}$ & Trieste, Italy & $\begin{array}{l}\text { Black rock, Kosi } \\
\text { Bay, KwaZulu- } \\
\text { Natal, South } \\
\text { Africa }\end{array}$ \\
\hline Habit & Mostly erect & Mostly erect & Mostly erect & $\begin{array}{l}\text { Decumbent, } \\
\text { small, axes aris- } \\
\text { ing on a layered } \\
\text { prostrate crusts }\end{array}$ & Mostly erect & Mostly erect \\
\hline Plant length & Up to $10.5 \mathrm{~cm}$ & Up to $5 \mathrm{~cm}$ & Up to $7.3 \mathrm{~cm}$ & Up to $3 \mathrm{~cm}$ & $10-20 \mathrm{~cm}(-25)$ & Up to $2 \mathrm{~cm}$ \\
\hline Axes & $\begin{array}{l}\text { Cylindrical, up to } \\
1.5 \mathrm{~mm} \text { wide }\end{array}$ & $\begin{array}{l}\text { Cylindrical, up to } \\
1.9 \text { mm wide }\end{array}$ & $\begin{array}{l}\text { Cylindrical, up to } \\
4.1 \mathrm{~mm} \text { wide }\end{array}$ & $\begin{array}{l}\text { Cylindrical, ca. } \\
0.5 \mathrm{~mm} \text { wide }\end{array}$ & Terete & $\begin{array}{l}\text { Cylindrical, ca. } \\
3 \mathrm{~mm} \text { wide }\end{array}$ \\
\hline $\begin{array}{l}\text { Indeterminate } \\
\text { branches }\end{array}$ & $\begin{array}{l}\text { Irregular or wide- } \\
\text { ly dichotomous, } \\
\text { rarely trichoto- } \\
\text { mous }\end{array}$ & $\begin{array}{l}\text { Irregular or wide- } \\
\text { ly dichotomous, } \\
\text { rarely trichoto- } \\
\text { mous }\end{array}$ & $\begin{array}{l}\text { Dichotomous or } \\
\text { irregular }\end{array}$ & $\begin{array}{l}\text { Unbranched or } \\
\text { branched once } \\
\text { to a few times }\end{array}$ & $\begin{array}{l}\text { Widely dichoto- } \\
\text { mous }\end{array}$ & Little branched \\
\hline $\begin{array}{c}\text { Determinate } \\
\text { branchlets }\end{array}$ & $\begin{array}{l}\text { Simple to } \\
\text { branched, up to } \\
6.5 \mathrm{~mm} \text { long }\end{array}$ & $\begin{array}{l}\text { Simple, 2-3 mm } \\
\text { long }\end{array}$ & $\begin{array}{l}\text { Simple, } 44-60 \\
\text { segments, up to } \\
7.7 \mathrm{~mm} \text { long }\end{array}$ & $\begin{array}{r}\text { Simple, less } \\
\text { developed }\end{array}$ & $\begin{array}{l}\text { Simple, (19-) } \\
\text { 29-49 segments }\end{array}$ & $\begin{array}{l}\text { Simple, relatively } \\
\text { at right angles } \\
\text { to the bearing } \\
\text { branch, articu- } \\
\text { lated in upper } \\
\text { portion, ca. } \\
3 \mathrm{~mm} \text { long }\end{array}$ \\
\hline $\begin{array}{l}\text { Surface cortical } \\
\text { cell packets }\end{array}$ & $2-4$ cells wide & $\begin{array}{l}\text { 2-4 cells wide, } \\
\text { irregularly }\end{array}$ & $\begin{array}{l}\text { Four cells wide, } \\
3-5 \text { cells in } \\
\text { central }\end{array}$ & $\begin{array}{l}\text { Arranged in } \\
\text { groups }\end{array}$ & $\begin{array}{l}\text { Two, rarely three, } \\
\text { cells wide, } \\
\text { parallel rows }\end{array}$ & $\begin{array}{l}\text { 1-3 cells wide, } \\
\text { irregularly }\end{array}$ \\
\hline $\begin{array}{l}\text { Outer cortical } \\
\text { cells }\end{array}$ & $\begin{array}{l}\text { One layered } \\
\text { (ca. } 20 \text { cells in } \\
\text { tier) }\end{array}$ & $\begin{array}{l}\text { One to two } \\
\text { layered (ca. } 30 \\
\text { cells in tier) }\end{array}$ & $\begin{array}{l}\text { One layered } \\
(17-34 \text { cells in } \\
\text { tier })\end{array}$ & $\begin{array}{l}\text { One to two } \\
\text { layered }\end{array}$ & $\begin{array}{l}\text { One layered } \\
(14-20(-24) \\
\text { cells in tier) }\end{array}$ & $\begin{array}{l}\text { Two layered } \\
\text { (ca. } 20 \text { cells in } \\
\text { tier) }\end{array}$ \\
\hline Pericentral cells & 8 , rarely 9 & 10 , rarely 8 & (8-) 9-12 cells & 10-12 cells & $7-10$ cells & $10-12$ cells \\
\hline Trichoblasts & $\begin{array}{l}\text { Deciduous, } \\
\text { developed on } \\
\text { apices }\end{array}$ & $\begin{array}{l}\text { Deciduous, } \\
\text { developed on } \\
\text { apices }\end{array}$ & $\begin{array}{l}\text { Deciduous, } \\
\text { developed on } \\
\text { apices }\end{array}$ & $\begin{array}{l}\text { Common, color- } \\
\text { less, pinnately } \\
\text { branched }\end{array}$ & $\begin{array}{l}\text { Deciduous, } \\
\text { developed on } \\
\text { apices }\end{array}$ & NA \\
\hline Tetrasporangia & $\begin{array}{l}\text { On inflated } \\
\text { determinate } \\
\text { branchlets, } \\
\text { tetrahedral, } \\
\text { 40-70 } \mu \mathrm{m} \text { diam. }\end{array}$ & NA & $\begin{array}{l}\text { On distorted } \\
\text { determinate } \\
\text { branchlets, } \\
\text { tetrahedral, } \\
\text { 38-82 } \mu \mathrm{m} \text { diam. }\end{array}$ & $\begin{array}{l}\text { Spirally arranged } \\
\text { along branch- } \\
\text { lets, tetrahedral, } \\
\text { ca. } 100 \mu \mathrm{m} \\
\text { diam. }\end{array}$ & $\begin{array}{l}\text { One per swollen } \\
\text { cell, on distorted } \\
\text { determinate } \\
\text { branchlets, } \\
\text { tetrahedral, 75- } \\
100 \mu \text { m diam. }\end{array}$ & $\begin{array}{l}\text { Immersed in dis- } \\
\text { torted determi- } \\
\text { nate branchlets, } \\
\text { tetrahedral }\end{array}$ \\
\hline Cystocarps & NA & NA & $\begin{array}{l}\text { Two or more } \\
\text { per branchlet, } \\
\text { urceolate, } 390- \\
500 \mu \mathrm{m} \text { diam. }\end{array}$ & $\begin{array}{l}\text { One per branch, } \\
\text { urceolate, } \\
300 \times 275 \mu \mathrm{m}\end{array}$ & Ovoid & NA \\
\hline Spermatangia & NA & NA & NA & $\begin{array}{l}\text { Forming capitula } \\
\text { on branch tips }\end{array}$ & $\begin{array}{l}\text { Forming flat, } \\
\text { oval discs }\end{array}$ & NA \\
\hline References & This study & This study & $\begin{array}{l}\text { Schneider et al. } \\
\text { (2018) }\end{array}$ & $\begin{array}{l}\text { Norris (1994) } \\
\text { (as Alsidium } \\
\text { cymatophilum) }\end{array}$ & $\begin{array}{l}\text { Kylin (1956), } \\
\text { Cabioc'h et al. } \\
\text { (2006), Schnei- } \\
\text { der et al. (2018) }\end{array}$ & Simons (1970) \\
\hline
\end{tabular}

NA, not applicable. 


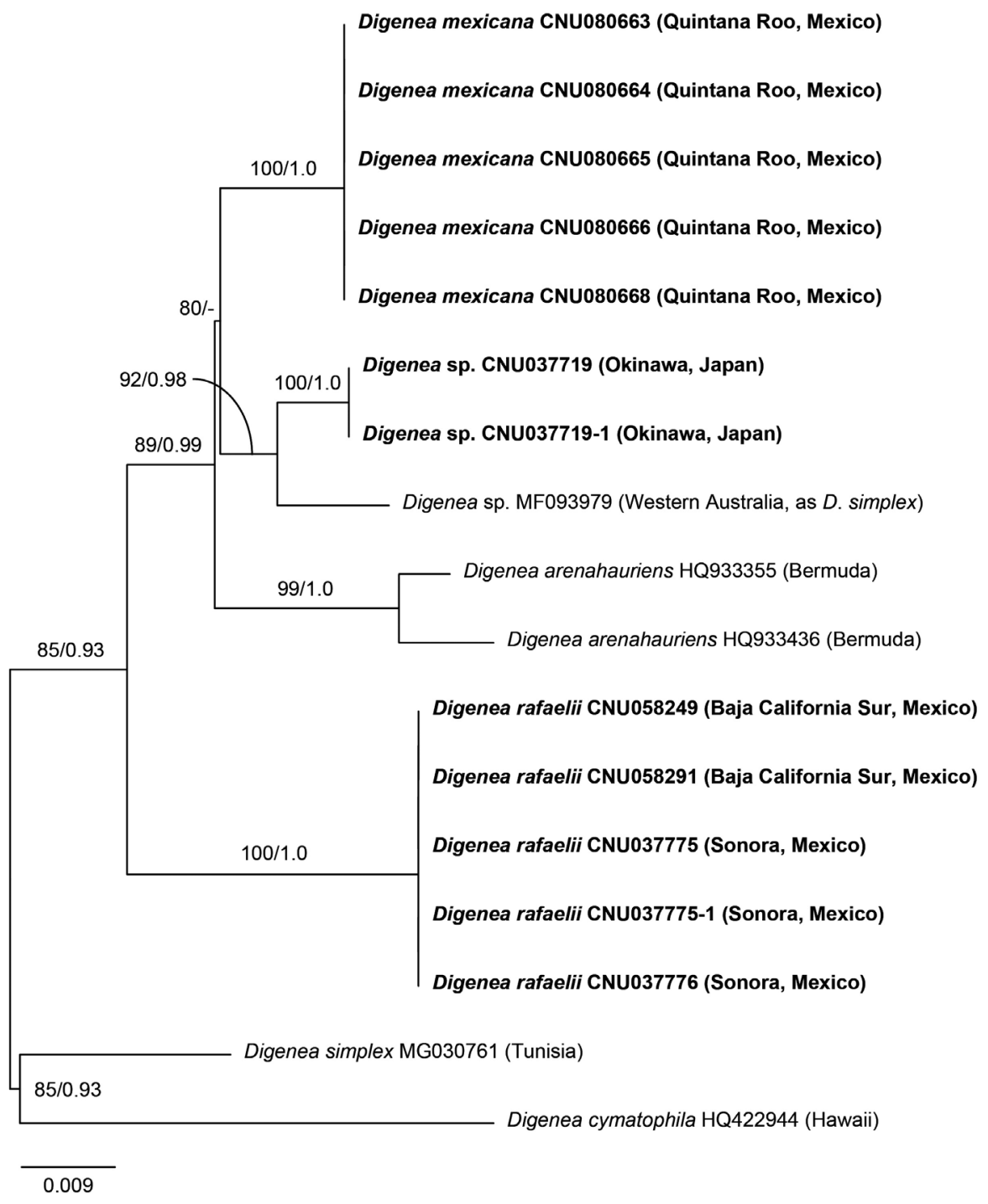

Fig. 3. Maximum likelihood (ML) tree inferred from mitochondrial COI-5P sequences of the genus Digenea. ML bootstrap values ( $\geq 50 \%)$ and Bayesian posterior probabilities $(\geq 0.90)$ are shown at branches. Dashes indicate values $<50$ or $<0.90$. Bold letters indicate newly generated sequences in this study.

\section{DISCUSSION}

Our results indicate that, based on COI-5P and $r b c \mathrm{~L}$ sequences, the D. simplex complex comprises more than six genetically distinct species, including $D$. mexicana sp. nov. and $D$. rafaelii sp. nov. from Mexico. Interestingly, $D$. mexicana on the Caribbean side is geographically isolated from $D$. rafaelii on the Pacific side, as the other species are endemic to their distributional range. All species can be recognized by comparative morphology (Table 1). The habit and size of plants, the presence or absence of indeterminate branches, the number of pericentral cells and the surrounding outer cortical cells, and branching of de- terminate branchlets can be used as diagnostic characters in segregating species, as discussed below. However, identification of Digenea species without DNA data and / or information on collection sites could prove difficult.

D. mexicana is distinct from $D$. rafaelii in morphology as well as COI-5P and $r b c \mathrm{~L}$ sequences. It occurs at Playa Xcalacoco, Quintana Roo on the Yucatan Peninsula. Plants grow to $10.5 \mathrm{~cm}$ tall and have cylindrical axes, irregular or widely dichotomous branches of indeterminate growth, simple to branched branchlets of determinate growth, eight pericentral cells in determinate branchlets and tetrasporangia formed in the upper inflated branchlets. Plants from Veracruz are large (about $14.5 \mathrm{~cm}$ tall in 


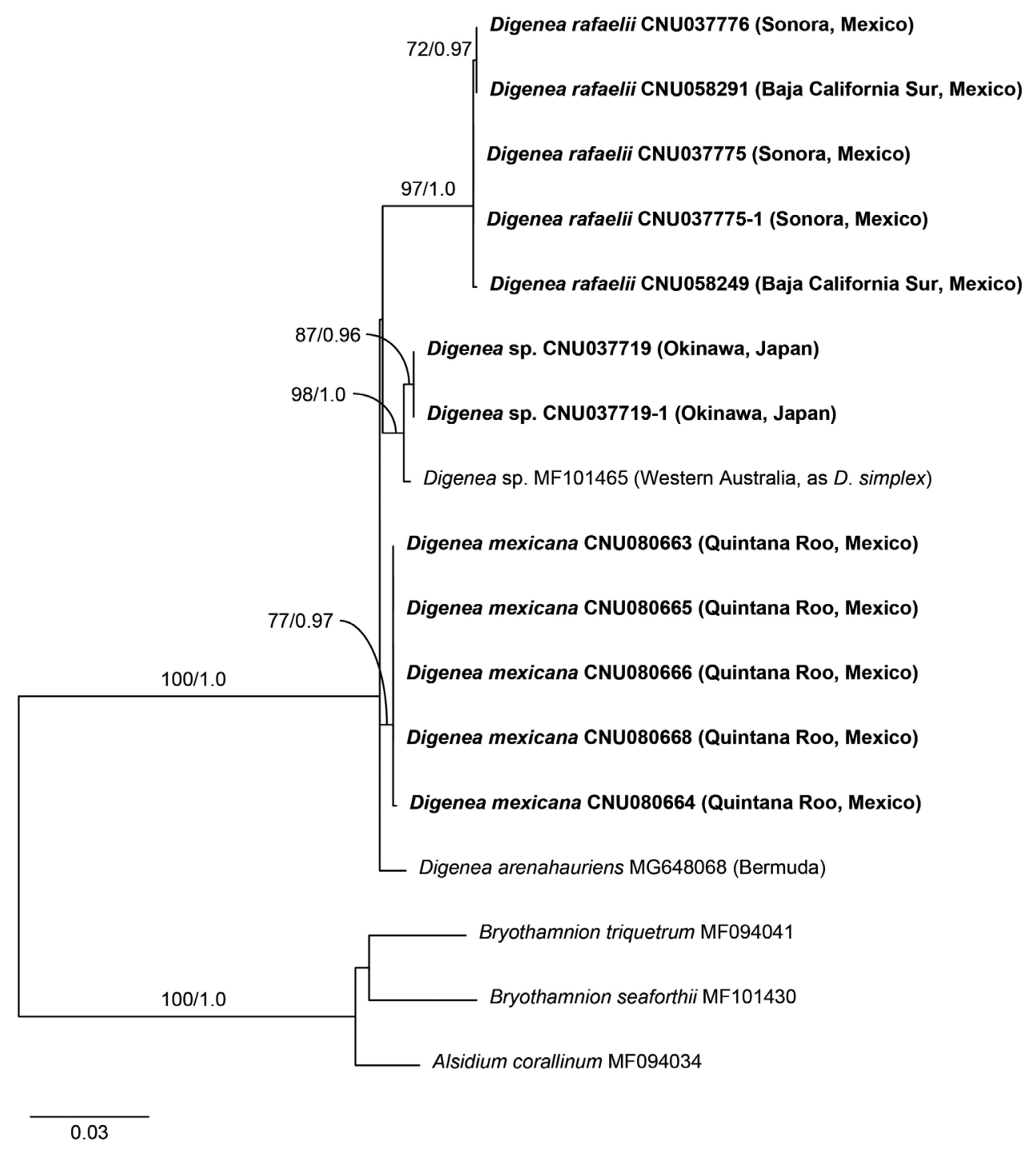

Fig. 4. Maximum likelihood (ML) tree inferred from plastid $r b c L$ sequences of the genus Digenea. ML bootstrap values ( $\geq 50 \%)$ and Bayesian posterior probabilities $(\geq 0.90)$ are shown at branches. Dashes indicate values $<50$ or $<0.90$. Bold letters indicate newly generated sequences in this study.

herbarium specimen of MEXU 2326), as comparable in size to the Mexican plant illustrated by Dreckmann and Sentíes (1994). Tetrasporangia were formed on the distal part of determinate branchlets, as reported in previous studies (Dawson 1963, Dreckmann and Sentíes 1994, Norris 2014). Mexican plants have a monophasic life history including only a tetrasporangial phase (Dreckmann and Sentíes 1994).

D. rafaelii occurs at four locations on the south and north coasts of the Baja California Peninsula. Plants grow to $5 \mathrm{~cm}$ tall and have cylindrical axes, irregular or widely dichotomous branches, and simple determinate branchlets with ten pericentral cells. The size of $D$. rafaelii is much smaller than that of D. mexicana. Plants from Baja California Peninsula have been reported to grow to $25 \mathrm{~cm}$ tall (Norris 2014), comparable to that of European plants of D. simplex (Kylin 1956, Cabioc'h et al. 2006), however plants in our collections are usually about $5 \mathrm{~cm}$ tall. Our specimens from Puerto Peñasco (collected in May 2010) and La Paz (collected in February 2015) were sterile without tetrasporangia and sexual reproductive structures. Populations of Digenea from the Pacific coasts of Mexico are mostly vegetative in the present and previous collections (Dreckmann and Sentíes 1994), although tetrasporangia were present only in specimens at Bahia de Kino in August and September (Mendoza-González and 
Mateo-Cid 1986). We could speculate that Baja California coasts is the northern boundary of $D$. rafaelii, where its populations might be maintained mostly by vegetative reproduction or mitotic tetrasporangia. Range of $\mathrm{D}$. $\mathrm{ra}$ faelii might be extended to Islas Revillagigedo and Costa Rican Golfo Dulce, where Digenea plants commonly occur (Taylor 1945, Dawson 1957).

D. arenahauriens (type locality: Captain William's Bay, Bermuda) grows to $7.3 \mathrm{~cm}$ tall and has terete main axes with long wiry determinate branchlets composed of 4460 axial segments (Schneider et al. 2018). Determinate branchlets grow to $7.7 \mathrm{~mm}$ long and have a relatively large axial cell (27-78 $\mu \mathrm{m}$ in diameter) with 9-12 pericentral cells surrounded by 17-34 outer cortical cells. Female plants have two or more cystocarps borne on a determinate branchlet. Tetrasporangia are formed subapically on determinate branchlets, are tetrahedrally divided and 38-82 $\mu \mathrm{m}$ in diameter (Schneider et al. 2018). D. arenahauriens occurs in Bermuda and the Caribbean Antilles (Schneider et al. 2018). Further study of Digenea in the Caribbean Sea will highlight the speciation and biogeographic patterns of $D$. arenahauriens and D. mexicana.

D. cymatophila (type locality: O'ahu Island, Hawaiian Islands) was transferred from Alsidium based on plastid genome data (Díaz-Tapia et al. 2017). It occurs on rocks in sandy beaches, forming a mass of erect determinate branches from a layered basal crust (Norris 1994). It develops only one cystocarp on each fertile branchlet of female plants. D. cymatophila is the sole decumbent species in Digenea, and the decumbent habit likely arose as a response to grazing pressure by herbivores (Lewis et al. 1987).

D. simplex (type locality: Trieste, Italy; the inner coast of Adriatic Sea) grows to $25 \mathrm{~cm}$ tall and has terete axes of indeterminate growth that are irregularly to dichotomously branched (Kylin 1956, Schneider et al. 2018). Determinate branchlets are wiry, with 29-49 segments and a relatively small axial cell (19-38 $\mu \mathrm{m}$ in diameter) and 7-10 pericentral cells surrounded by 14-20 (-24) outer cortical cells (Kylin 1956, Schneider et al. 2018). It occurs throughout the year in the Mediterranean except the Gulf of Lion (Cabioc'h et al. 2006).

D. subarticulata (type locality: Black Rock, Kosi Bay, KwaZulu-Natal, South Africa) is small in size (less than 2 $\mathrm{cm}$ tall) and has simple axes with 10-12 pericentral cells (Simons 1970). Determinate branchlets are relatively long and slightly articulated at the upper portion (Simons 1970). De Clerck et al. (2005) noted that D. subarticulata is likely representative of Bryothamnion, because of its small size and occurrence apart from northern KwaZuluNatal, where is the southern boundary of Digenea.

Both COI-5P and $r b c$ L phylogenies indicate that Digenea plants from Japan and Australia, in the past referred to D. simplex (Yoshida 1998, Huisman and Borowitzka 2003), are different species from $D$. simplex from Tunisia. Considering that the type locality of $D$. simplex is Trieste, Mediterranean samples could be considered as typical. The close relationships $(1.5 \%$ in COI-5P, $0.4 \%$ in $r b c \mathrm{~L})$ between the Japanese and Australian taxa suggest their recent divergence from a common ancestor, which has likely occurred widely from southern to northern hemispheres. Additional study is needed to unravel the phylogenetic bridge between Western Australia and Japan and to decide whether plants from Australia and Japan belong to the same species or are distinct species.

We dispute the merging of New Caledonian Digenea vieillardii Kützing into D. simplex by De Toni (1903) and Millar and Prud'homme van Reine (2005), who considered the former species as a heterotypic synonym of the latter. Kützing (1865) described D. vieillardii on the basis of specimens that Eugène Vieillard, a French botanist, collected during his expedition to New Caledonia. The diagnosis was "Ramellis ramosis", and the branched determinate branchlets were well illustrated in Tabulae $28 \mathrm{~g}, \mathrm{~h}$, I, k, l in the protologue (Kützing 1865). Our present study supports the taxonomic value of branched determinate branchlets in Digenea because it characterizes D. mexicana from D. rafaelii. D. vieillardii has tetrachotomous to verticillate branchlets at the upper part, while determinate branchlets of D. mexicana are mostly formed once. In contrast, $D$. simplex has simple, unbranched determinate branchlets (Kylin 1956, Schneider et al. 2018). Molecular analysis of type or topotype material of D. vieillardii is necessary to unravel its phylogenetic relationship within Digenea.

This is the first study of the genetic discontinuity between Digenea plants from Mexico, where we describe two new species, D. mexicana in Yucatan Peninsula and D. rafaelii in the Gulf of California. The previous reports of D. simplex in Australia and Japan (Yoshida 1998, Huisman and Borowitzka 2003) are misidentifications due to the cryptic nature of the $D$. simplex complex. Further global sampling will highlight taxonomy and distribution patterns of the D. simplex complex. Since D. simplex is one of the major medicinal red algae (Ebadi 2006), our finding will contribute to its medicinal exploitation and the conservation of local species. 


\section{SUPPLEMENTARY MATERIAL}

Supplementary Table S1. Information on specimens included in molecular analyses (http://e-algae.org).

\section{ACKNOWLEDGEMENTS}

We thank Rafael Riosmena-Rodriguez for his help in collection in Baja California Peninsula, José Luis Godinez-Ortega from MEXU for herbarium on loan, and Marina Morabito for COI-5P sequence of the Tunisian sample. The first author thanks field guiders in the precongress tours of 2009 IPC in Okinawa, Japan. This study was supported by a postdoctoral scholarship from the Silva Center for Phycological Documentation, University Herbarium, University of California Berkeley to GHB, PN-Conacyt: 2015-01-575 to DR, and a grant of Marine Biotechnology Program (2017143), Korean Ministry of Oceans and Fisheries to SMB. We appreciate John Huisman and anonymous reviewers for improving our manuscript.

\section{REFERENCES}

Agardh, C. A. 1822. Species algarum rite cognitae, cum synonymis, differentiis specificis et descriptionibus succinctis, Volumen primum pars posterior. Ex officina Berlingiana, Lundae, pp. 169-398.

Benson, D. A., Cavanaugh, M., Clark, K., Karsch-Mizrachi, I., Ostell, J., Pruitt, K. D. \& Sayers, E. W. 2018. GenBank. Nucleic Acids Res. 46:D41-D47.

Boo, G. H., Hughey, J. R., Miller, K. A. \& Boo, S. M. 2016a. Mitogenomes from type specimens, a genotyping tool for morphologically simple species: ten genomes of agarproducing red algae. Sci. Rep. 6:e35337.

Boo, G. H., Le Gall, L., Miller, K. A., Freshwater, D. W., Wernberg, T., Terada, R., Yoon, K. J. \& Boo, S. M. 2016b. A novel phylogeny of the Gelidiales (Rhodophyta) based on five genes including the nuclear CesA, with descriptions of Orthogonacladia gen. nov. and Orthogonacladiaceae fam. nov. Mol. Phylogenet. Evol. 101:359-372.

Boo, G. H., Park, J. K. \& Boo, S. M. 2013. Gelidiophycus (Rhodophyta: Gelidiales): a new genus of marine algae from East Asia. Taxon 62:1105-1116.

Cabioc'h, J., Floc'h, J. -Y., Le Toquin, A., Boudouresque, C. -F., Meinesz, A. \& Verlaque, M. 2006. Guide des algues des mers d'Europe. Delachaux et Niestlé, Paris, 272 pp.

Dawson, E. Y. 1957. Marine algae from the Pacific Costa Ri- can Gulfs. Los Angeles County Mus. Contrib. Sci. 15:128.

Dawson, E. Y. 1963. Marine red algae of Pacific Mexico. Part 8. Ceramiales: Dasyaceae, Rhodomelaceae. Nova Hedwigia 6:401-481.

De Clerck, O., Bolton, J. J., Anderson, R. J. \& Coppejans, E. 2005. Guide to the seaweeds of KwaZulu-Natal. National Botanic Garden of Belgium, Meise, 294 pp.

De Toni, J. B. 1903. Sylloge Algarum omnium hucusque cognitarum, Vol. 4. Florideae, Section III. Sumptibus auctoris, Padua, pp. 777-1521.

Díaz-Tapia, P., Maggs, C. A., West, J. A. \& Verbruggen, H. 2017. Analysis of chloroplast genomes and a supermatrix inform reclassification of the Rhodomelaceae (Rhodophyta). J. Phycol. 53:920-937.

Dreckmann, K. M. \& Sentíes, G. A. 1994. El alga Digenea simplex (Ceramiales: Rhodomelaceae) en México: variación biogeográfica. Rev. Biol. Trop. 42:443-453.

Ebadi, M. 2006. Pharmacodynamic basis of herbal medicine. 2nd ed. CRC Press, London, 699 pp.

Freshwater, D. W. \& Rueness, J. 1994. Phylogenetic relationships of some European Gelidium (Gelidiales, Rhodophyta) species based on $r b c \mathrm{~L}$ nucleotide sequence analysis. Phycologia 33:187-194.

Guiry, M. D. \& Guiry, G. M. 2018. AlgaeBase. World-wide electronic publication, National University of Ireland, Galway. Available from: http://www.algaebase.org. Accessed May 4, 2018.

Huisman, J. M. \& Borowitzka, M. A. 2003. Marine benthic flora of the Dampier Archipelago, Western Australia. In Wells, F. E., Walker, D. I. \& Jones, D. E. (Eds.) The Marine Flora and Fauna of Dampier, Western Australia. Western Australian Museum, Perth, pp. 291-344.

Kang, J. C. \& Kim, M. S. 2013. A novel species Symphyocladia glabra sp. nov. (Rhodomelaceae, Rhodophyta) from Korea based on morphological and molecular analyses. Algae 28:149-160.

Kützing, F. T. 1865. Tabulae Phycologicae: oder, Abbildungen der Tange. Vol. 15. Gedrucht auf kosten des Verfassers, Nordhausen, 33 pp.

Kylin, H. 1956. Die Gattungen der Rhodophyceen. C.W.K. Gleerups Förlag, Lund, 673 pp.

Lewis, S. M., Norris, J. N. \& Searles, R. B. 1987. The regulation of morphological plasticity in tropical reef algae by herbivory. Ecology 68:636-641.

Mendoza-González, A. C. \& Mateo-Cid, L. E. 1986. Flora marina bentónica de la coasta noroeste del estado de Sonora, México. Phytologia 60:414-427.

Millar, A. J. K. \& Prud'homme van Reine, W. F. 2005. Marine benthic macroalgae collected by Vieillard from New 
Caledonia and described as new species by Kützing. Phycologia 44:536-549.

Norris, J. N. 2010. Marine algae of the Northern Gulf of California: Chlorophyta and Phaeophyceae. Smithson. Contrib. Bot. 94:1-276.

Norris, J. N. 2014. Marine algae of the Northern Gulf of California II: Rhodophyta. Smithson. Contrib. Bot. 96:1-555.

Norris, R. E. 1994. Some cumophytic Rhodomelaceae (Rhodophyta) occurring in Hawaiian surf. Phycologia 33:434-443.

Orfanidis, S. \& Breeman, A. M. 1999. Geographic variation in thermal traits in Digenea simplex and Champia parvula (Rhodophyta) in relation to present and glacial temperate regimes. J. Phycol. 35:919-930.

Pakker, H., Klerck, H., van Campen, J. H., Olsen, J. L. \& Breeman, A. M. 1996. Evolutionary and ecological differentiation in the pantropical to warm-temperate seaweed Digenea simplex (Rhodophyta). J. Phycol. 32:250-257.

Pereira, J. G., Mesquita, J. X., Aragão, K. S., Franco, A. X., Souza, M. H. L. P., Brito, T. V., Dias, J. M., Silva, R. O., Medeiros, J. -V. R., Oliveira, J. S., Abreu, C. M. W. S., de Paula, R. C. M., Barbosa, A. L. R. \& Freitas, A. L. P. 2014. Polysaccharides isolated from Digenea simplex inhibit inflammatory and nociceptive responses. Carbohydr. Polym. 108:17-25.

Ronquist, F., Teslenko, M., van der Mark, P., Ayres, D. L., Darling, A., Höhna, S., Larget, B., Liu, L., Suchard, M. A. \& Huelsenbeck, J. P. 2012. MrBayes 3.2: efficient Bayesian phylogenetic inference and model choice across a large model space. Syst. Biol. 61:539-542.

Saunders, G. W. \& Moore, T. E. 2013. Refinements for the application and sequencing of red algal DNA barcode and RedToL phylogenetic markers: a summary of current primers, profiles and strategies. Algae 28:31-43.

Schneider, C. W., Hamzeh, B. F., Lane, C. E. \& Saunders, G.
W. 2018. A new species of Digenea (Rhodomelaceae, Ceramiales) based upon a molecular assessment and morphological observations of plants historically known as D. simplex in Bermuda. Phytotaxa 338:90-98.

Silva, P. C., Basson, P. W. \& Moe, R. L. 1996. Catalogue of the benthic marine algae of the Indian Ocean. Univ. Calif. Publ. Bot. 79:1-1259.

Simons, R. H. 1970. Marine algae from southern Africa. 1. Six new species from the inter- and infra-tidal zones. Invest. Rep. Div. Sea Fish. S. Afr. 88:1-13.

Stamatakis, A. 2014. RAxML version 8: a tool for phylogenetic analysis and post-analysis of large phylogenies. Bioinformatics 30:1312-1313.

Takano, R., Shiomoto, K., Kamei, K., Hara, S. \& Hirase, S. 2003. Occurrence of carrageenan structure in an agar from the red seaweed Digenea simplex (Wulfen) C. Agardh (Rhodomelaceae, Ceramiales) with a short review of carrageenan-agarocolloid hybrid in the Florideophycidae. Bot. Mar. 46:142-150.

Taylor, W. R. 1945. Pacific marine algae of the Allan Hancock Expedition to the Galapagos Islands. Allan Hancock Pac. Exped. 12:1-528.

Thiers, B. 2018. Continuously updated. Index Herbariorum: a global directory of public herbaria and associated staff. New York Botanical Garden's Virtual Herbarium. Available from: http://sweetgum.nybg.org/ih/. Accessed Jun 10, 2018.

Trono, G. C. Jr. 1997. Field guide and atlas of the seaweed resources of the Philippines. Bookmark Inc., Makati, 303 pp.

Tseng, C. K. 1983. Common seaweeds of China. Science Press, Beijing, 316 pp.

Yoshida, T. 1998. Marine algae of Japan. Uchida Rokakuho, Tokyo, 1222 pp. 